\title{
THE SPIRITUAL ROLE OF PESANTREN IN SHAPING INDONESIAN CIVILIZED MUSLIMS
}

\author{
Jaenullah \& Sudadi \\ Dosen Tetap Pascasarjana IAINU Kebumen \\ Email: jejen.jaenullah@gmail.com \\ Email: sudadi.klirong@gmail.com
}

\begin{abstract}
:
As an Islamic educational Institution, Indonesian pesantren play roles in spiritually shaping Indonesian civilized Muslims. Since the beginning of pesantren spiritual teachings were installed pesantren founding fathers. Through such teachings, the students of pesantren can be the agents of Indonesian civilized Muslims who behave tolerantly, peacefully and friendly towards otherness and diversity in Indonesia. However, Pesantren have to develop in terms of their education system and management to deal with the phase of contemporary development of education. Yet, the core of spirituality in nuancing the pesantren education system and management has to be pertained and maintained. This article is to reveal such issues in relation to history and recent problems.
\end{abstract}

Keywords: spirituality, pesantren, education, Indonesian civilized muslims

\section{A. Introduction}

$\bigcap$ he potential of pesantren as a center of civilized Muslims in Indonesia is manifested in the form of intellectual treasures inherent in the pesantren in the form of the "yellow book" tradition, in addition to other traditions such as the attitudes and behaviors of tasamuh, tawassuth, and tawazun. ${ }^{1}$

In the current context, the discussion about the existence of pesantren in the framework of Islamic education in Indonesia is something that is felt to be increasingly

1 These three attitudes and behaviors (tasamuh, tawassuth, and tawazun) as adopted in the "khittoh" of Nahdlatul Ulama (NU) thought and amaliyah, a largest Islamic organization in Indonesia that are identical with the world of pesantren, are related to the social attitudes of the NU citizens. Tasamuh means tolerance in religious dissent, including in social and cultural matters. Tawassuth means "middle attitude" which is based on justice in the midst of shared life, and is a role model, acts straight, is constructive and is not extreme. Tawazun means balance in serving Allah Almighty, serving human beings and the environment, and harmony of thought between the past, present and future. See Zamzami M, Islam Ahlussunnah Waljamalah di Indonesia: Sejarah, Pemikiran, dan Dinamika Nahdlatul Ulama, (Jakarta: Pustaka Ma'arif NU, 2007), 183-187 
important. With the issuance of Law on National Education System No. 20 of 2003 and Government Regulation No. 55 of 2007 concerning Religious and Religious Education, pesantren such as getting a new "ammunition" which positions it formally on a par with other educational models (formal education) in the presence of Government Laws and Policies. This condition is certainly very positive as well as a challenge for the nowadays and future of pesantren.

So far, based on data from the Diniyah Education Directorate and Islamic Boarding School of the Indonesian Ministry of Religion, in terms of quantity the number of pesantren in Indonesia has now reached more than 14,067 with the number of students as many as $3,149,374$. Of the 300 , more than 8,000 pesantren are salafiyahstyle pesantren. The Salafiyah pesantren focuses on religious learning through the study of the yellow book. While, the rest are non-salafiyah pesantren in which their activities are carried out in formal schools or madrasas in addition to studying in pesantren.

Even so, with the dynamics and development of the times and situations, there are not a few challenges and demands that require pesantren to immediately make efforts to reform and have better future development steps. In addition to being related to the basic elements in pesantren, the problem of restoring the image of pesantren which in recent years was "tarnished" due to the brutal actions of a handful of terrorists linked to certain pesantren, is something that must also be considered and anticipated seriously. This is very important to realize the potential of pesantren as the center of Islamic civilization in Indonesia, at the same time to display the face of Indonesian Islam in the eyes of a peaceful and tolerant international world in accordance with the spirit of the pesantren.

Based on the above facts, the writing of this paper focuses on the pesantren spiritual role as the center of the tradition of Islamic civilization in the archipelago. In order to make the center of Islamic civilization, this paper argues for four things that have been done by pesantren to further educating people the reconstruction of pesantren education, reforming the pesantren system and management, strengthening pesantren culture, and government policy support. Before explaining pesantren as the center of spiritual education for shaping Indonesian civilized Muslims, it will initially tells about the development of pesantren in terms of understanding and history, pesantren traditions, and the development and function of pesantren.

\section{B. Development of the Pesantren in the Archipelago}

The word system comes from Latin (systēma) and Greek (sustēma) is "A unit consisting of components or elements that are linked together to facilitate the flow of information, material or energy to achieve a goal". Thus in a system, every components 
or elements composed in it are seen from the function as a unit. In the pesantren education system there are elements of the pesantren education system. Mastuhu revealed elements in the pesantren education system including: (a) objectives; (b) philosophy and values; (c) pesantren organizational structure; institutional status, organizational status, leadership style, and leadership succession: (d) the pesantren's living environment; (e) kiai and religious teacher; (f) santri; (g) management; (h) behavioral interactions; (i) curriculum and learning resources; (j) teaching and learning process and evaluation; (k) management and funds; (1) educational facilities and tools. ${ }^{2}$

Next there are several opinions about the origin of the understanding of the word "pesantren". Prof. John argues, that the word pesantren comes from the term "santri" which is derived from the Tamil language which means "teacher recites". While C.C. Berg argues, according to him, that the word santri comes from the Indian language "shastri" which means "one who has knowledge of the scriptures". Unlike the two, Robson argues that the word santri comes from the Tamil language "sattiri" which means "people who live in a shack house or religious building in general". ${ }^{3}$

Another opinion says that students come from Sanskrit. "Cantrik" which means "one who always follows the teacher". There is also an opinion which states that santri were originally a combination of the words "saint" (good human) and "tra" (like helping), so that the word pesantren is interpreted as a place of good human education. ${ }^{4}$ Meanwhile, according to Abudin Nata, the word "pesantren" comes from the word "pesantrian" which means dormitory and a place where students learn to recite. ${ }^{5}$ Meanwhile, Zamahkhsyari Dhofier defines pesantren as a place to study santri, while pondok means simple house or residence made of bamboo. ${ }^{6}$

Apart from differences of opinion regarding the origin of the word pesantren, what is important to underline is that pesantren is the oldest Islamic educational institution that has remained consistent to this day in maintaining values, culture or traditions, and strong religious beliefs. In fact, pesantren is an educational institution recognized from the very beginning to be very independent.

In this case, Malik Fadjar in Amin Haedari once boasted of the independence of this pesantren by saying that in terms of independence, pesantren are clearly superior to tertiary institutions which, although seemingly "wow", are actually educational

2 Mastuhu, Dinamika Sistem Pendidikan Pesantren dan Madrasah, (Yogyakarta: Fakultas Tarbiyah IAIN Walisongo in cooperation with Pustaka Pelajar, 1992), 174-175

3 Karel A. Steenbrink, Pesantren, Madrasah, Sekolah, (Jakarta: LP3ES, 1974), 15

$4 \quad$ Ibid.

5 Abudin Nata, Pendidikan Islam dengan Pendekatan Multidisipliner, (Jakarta: PT RajaGrafindo Persada, 2010), 170

6 Zamakhsyari Dhofier, Tradisi Pesantren, (Jakarta: LP3ES, 2002), 18

Teosofia: Indonesian Journal of Islamic Mysticism, Vol. 7, No. 2, 2018 
institutions that should be most responsible for the booming unemployment rates in the community. ${ }^{7}$

Historically, although pesantrens in the sense of educational institutions where textual teaching only emerged around the 18th century, historical records state that the establishment of pesantren actually existed since the early days of the spread of Islam in Indonesia, especially in Java. The figure who first founded the pesantren was Maulana Malik Ibrahim (died 1419 AD). Maulana Malik Ibrahim uses mosques and pesantren for the teaching of Islamic sciences, which in turn gave birth to Walisongo figures who also established pesantren in their respective areas, such as Sunan Ampel in Surabaya, Sunan Giri in Gresik, Sunan Bonang in Tuban, Sunan Drajat in Lamongan, and Raden Fatah in Demak. In fact, it was noted later, Giri's pesantren students were instrumental in spreading Islam in Java and Madura, including islands in eastern Indonesia, such as Lombok, Sumbawa, Bima, Makasar, Ternate, Kangean to Maluku. ${ }^{8}$

In subsequent periods as was the case with Walisongo, the process of establishing Islamic boarding schools was never separated from the presence of a cleric who aspired to spread Islam in his area. These scholars have usually lived for several years to study and explore Islamic religious knowledge, both in Islamic boarding schools in Indonesia as well as in Mecca and Medina. After returning to his place of origin, he then established a "surau" for use in congregational prayers and other activities. Most pesantren are privately founded by a kyai. This is a factor that strengthens the existence of pesantren, although this factor also, which if not reinforced by other supporting factors will make certain pesantren become weak or die. In fact, because of the charisma and influence possessed, not a few clerics or scholars who are considered by the community as the forerunner to the establishment of an area. As an Islamic educational institution, each pesantren has at least 5 (five) basic elements, namely: mosque or musholla, clerics or caretakers of pesantren, santri, boarding or boarding students, and teaching the books (classical book).

According to Martin Van Brunessen's notes, there were no institutions like pesantren in Kalimantan, Sulawesi and Lombok before the 20th century. The transmission of Islamic sciences there is still very informal. Children and villagers learn to read and memorize the Qur'an only from the people of their own village who are first to master. If there is a pilgrimage or Arab traders who happen to stop in the village, the villagers will ask him to stop for a few days to teach the books and teachings of Islam. Local clerics in several areas also provide general studies to the

Amin Haedari, dkk., Masa Depan Pesantren dalam Tantangan Modernitas dan Tantangan Kompleksitas Global, (Jakarta: IRD Press, 2004), 53.

8 HS. Mastuki dan M. Ishom El-Saha (eds.), Intelektualisme Pesantren: Potret Tokoh dan Cakrawala Pemikiran di Era Pertumbuhan Pesantren, (Jakarta: Diva Pustaka, 2003), 8. 
community at the mosque. Students who are very interested will come to study and even stay at home. Students who want to study further will usually go to Java, or if possible go to Mecca. That is the situation in Java and Sumatra in the first centuries of the spread of Islam. ${ }^{9}$

Thus the pesantren has become a center for the spread of Islam which is very effective in Indonesia since its inception. This success is supported by the important position of the kyai, ajengan, tengku, mister guru, or other religious leaders in the community. They are not only seen as advisors in the spiritual field, but are considered charismatic figures for students (santri) and their communities.

\section{Pesantren Traditions}

The word tradition comes from English. In Indonesian, tradition means everything (such as customs, beliefs, habits, teachings, etc.) ${ }^{10}$ Pesantren is a typical form of Islamic education model in the archipelago. Although pesantren are traditional Islamic educational institutions, in some aspects pesantren are unique compared to other traditional Islamic educational institutions in the world. At the same time, pesantren actually has an international orientation, with Mecca as the center of its orientation, not Indonesia. For example, the tradition of "the yellow book", obviously not from Indonesia. All the yellow books studied in Indonesia use Arabic, and most were written before the teachings of Islam spread in Indonesia. In fact, the main attention shifts in the tradition of the yellow book too in line with similar shifts that have taken place in much of the Islamic world. A number of yellow books studied at pesantren, although relatively new, were not written in Indonesia, but in Mecca and Medina.

The existence of pesantren which cannot be separated from the tradition of the study of the yellow book as its main literature, makes the existence of pesantren as a traditional Islamic educational institution in Indonesia maintained. In the pesantren it can be said that there is no uniformity of the curriculum related to the book being studied. In fact, some pesantren specialize themselves in certain fields of science in accordance with scientific disciplines undertaken by the kyai (pesantren takhassus), although of course by staying without ignoring other fields of science. What is highly considered by Islamic boarding schools is the selectivity of the books taught to the students (your books' tabarah). Almost all the books studied in pesantren are schools of madzhab and are very concerned about the status of the books until they reach the author.

9 Martin Van Brunessen, Kitab Kuning: Pesantren dan Tarekat, (Bandung: Mizan, 1999), 13
10 W.J.S Poerwadarminta, Kamus Umum Bahasa Indonesia, (Jakarta: Balai Pustaka, 1991), 1089

Teosofia: Indonesian Journal of Islamic Mysticism, Vol. 7, No. 2, 2018 
The pesantren tradition that always studies and discusses all issues of social life based on the yellow book has made the pesantren have its own form. In dealing with various problems, both religious and social problems, pesantren always use the yellow book as a reference, written by the salafus shalih scholars.

Besides the yellow book tradition, there are still many other traditions and noble values developed in pesantren, such as the attitudes and behavior of tasamuh, tawassuth, and tawazun. Tasamuh means tolerant in differences of religious opinion, and in social and cultural matters. Tawassuth means middle attitude that intends justice in the midst of shared life, and becomes a role model, acts straight, is constructive and not extreme. Tawazun means balance in serving Allah SWT, serving fellow humans and the environment, and harmony between the past, present and future. ${ }^{11}$

\section{Pesantren and Spirituality}

Early pesantren were built in the era of the Walisongo (nine saints) besides teaching Sharia science in the form of reading Qur'an, Fiqh and procedures of worship too always with an emphasis on importance riyadhoh / tirakat $^{12}$ in order to purify the mind and wisdoms related to spiritualism. Early period of the saints were also familiar with karomah stories ${ }^{13}$ arising from inner cleanliness and penance so miracles His supernatural powers helped in preaching activities. ${ }^{14}$

Based on the history, Spiritual education aims to create opportunities to listen to this inner voice, to get greater clarity as to why we were created and what unique mission might be. According to the Kabbalah, these are three different sounds of the soul. "They are expressed through the body (Nefesh), the heart (Ruach), end the mind (Neshama)". They are expressed through the body (Thing), heart (Ruach), and mind (Neshama). Mind, heart, and body ideally, these three elements interact harmoniously with each other no part of the individual is either ignored or rejected. According to AlGhazali man was created by God as a creature consisting of soul and body. The soul

11 Zamzami M, dkk., Islam Ahlussunnah, 183-187

12 The word tirakat is an explanation of the Arabic word, Tariqah, which means "the path". Language Indonesia then absorbs this word into penance and tirakatan. Tirakat means undergoing spiritual practice for achieve what you want. Also called by among the pesantren with riyadhah, which is undergoing behavior control and curb lust. See: http: //www.nu.or.id/post/read/40738/tirakat

13 Karomah is a divine gift by Allah SWT to his chosen and nature servants like miracles bestowed on prophets and apostles, between the two have in common that miracles and karomah can occur solely because of permission from Allah SWT and is not his own wish. Karomah trustees have the ability to do extraordinary and beyond human reason given to his loved ones known as waliyullah, where the saints of Allah are able to show an extraordinary event as one help Allah, to his pious servants, one of them when is doing religious and religious propaganda.

14 Agus Sunyoto, ATLAS WALI SONGO (Buku Pertama yang Mengungkap Wali Songo Sebagai Fakta Sejarah), 413 
that is at the core of human nature is a very divinely subtle spiritual rabbani being (lathif rabbaniyyah ruhaniyyah). ${ }^{15}$

The soul is in the spiritual realm while the body is in the material realm. The soul originates from the divine has nature (ash al-fitrah), that is its tendency to goodness and aversion to abomination. The nature of this soul tends to get nur (light) which is called al-ghazali as ma'rifat into his heart, he can accept the truth of knowledge that comes from Allah SWT. So that with ma'rifat in the hearts of the salik (spiritual practitioners) closer to God. The term spiritual education of the Islamic world is known as Sufism. Sufism is a science that understands and lives the experiences of the Prophet Muhammad through his life. Al-Ghazali and Junaid alBaghdadi provide an understanding of spiritual education (Sufism) by teaching to be a people who have individual piety and social piety (congregation), always dynamic and can compare between offers of pleasure meeting with God and at the same time can solve the problems faced by the people. From the description of spiritual education above, it can be taken the understanding that spiritual education is a personal education, by honing the mind, heart, and body in treading experiences as an effort to draw closer to God.

According to Dr. Abdul Munir Mulkhan, spiritual education is known as personality education which is based on emotional and spiritual intelligence (ruhmania) which relies on self problems. ${ }^{16}$ Balance using emotional and spiritual intelligence will create our human beings, while at the same time being able to become people who have individual piety and social piety. There are fundamental differences between educating and teaching, some people may be caught between the definition of educating with teaching. In fact, there are fundamental differences between the two. Teaching is a daily technical activity of a teacher. All teacher preparation for teaching is technical. The results can also be measured by verbalistic instrument of behavior change. Not all education is learning, on the contrary not all learning is education.

The difference between educating and teaching is very thin, it can simply be said that good teaching is educating. In other words educating can use the teaching process as a means to achieve maximum results in achieving educational goals Educating more is a medium-term or long-term activities. Educational results cannot be seen anytime soon or instantly.

Education is an integrative activity of thought, taste, and if that synergizes with the development of the level of reasoning of students. Teaching that is followed by teaching and learning activities in synergy so that the material delivered can increase scientific insight, growth of skills and produce changes in mental attitude /

15 Hasyimsyah Nasution, Filsafat Islam, (Gaya Media: Jakarta, 2007), 89

16 Abdul Munir Mulkham, Nalar Spiritual Pendidikan, (Tiara Wacana Yogya: 2007), 73

Teosofia: Indonesian Journal of Islamic Mysticism, Vol. 7, No. 2, 2018 
personality, in accordance with absolute values and relative values that apply in the community and nation environment for children students are educational activities. Educating the weight is the formation of mental attitude / personality for students, while teaching the weight is the mastery of certain knowledge, skills and expertise that takes place for all humans at all ages. For example, a mathematics teacher teaches smart children to count, but the child is not full of calculations in all his actions, then the teacher's activities are limited to teaching not educating.

One of the characteristics is the desire and the need to develop a culture and even pass it on to the next generation. This is what actually becomes the arable field of education starting from its simple form to an education that has an advanced, complete, and perfect system. The more advanced a peradap will be more advanced and perfect the educational system that is formed whose purpose is as an effort to pass down, develop, maintain culture and civilization itself. Each culture forms a unique pattern and pattern of education. It can be understood that a liberalist will form a pattern of liberal propagation and will lead others to become liberalists. An atheist will form an atheist pattern to become someone else making atheists as well as someone who adheres to a religious belief will form a pattern of education in accordance with his beliefs. ${ }^{17}$

Spiritual education in the context of pesantren in this paper is defined as a concept, an education system that emphasizes the development of spiritual or spiritual abilities with spiritual standards that can be felt by students to achieve the perfection of life according to Islamic standards. The development of spiritual abilities is not limited to students, but includes all educational advancements. This departs from the assumption that educating and following education is worship. ${ }^{18}$

Worship functionally aims at spiritual enlightenment. Spiritual education is based on the belief that educational activities are worship of God Almighty. Humans were created as servants of the holy God and were given the mandate to maintain the sanctity. In general, spiritual education focuses on spirituality as the main potential in mobilizing every act of education and teaching, in this case understood as a source of inspiring normative in educational and teaching activities, and at the same time spirituality as an educational goal. ${ }^{19}$

The main concept of spiritual-based education is the value of Qur'an and the hadith of the Prophet Muhammad, that is the Qur'an contains complete values and provisions in human life. ${ }^{20}$ In this case the position of the Prophet's hadith occupies the

\footnotetext{
17 Ahmad Rivauzi, Pendidikan Berbasis Spiritual, (Jakarta: Bumiayu, 2007), 97

18 Ibid.

19 Ibid.

20 Ibid.
} 
second source which acts as an explanation of the legal cues and values contained in the Qur'an. The role of the Qur'an in the life of science and life, law, social, and culture of Muslim communities can be illustrated in the word of Allah SWT QS. Al Baqarah verses 2-5: 31 Meaning: This Book (Al Quran) has no doubt about it; guidance for those who are devout, (ie) those who believe in the unseen, who establish prayers and spend part of the fortune that we bestow on them, and those who believe in the book (the Koran) which has been revealed to you and the Books that have been revealed before you and they are convinced of the existence (of life) of the hereafter. Those are the ones who keep getting guidance from their Lord, and they are the lucky ones. ${ }^{21}$

In the verse above, it explains that the essence of human existence in this world is to worship and carry out what He has commanded His people. As a guide, he sent down the Qur'an. And to restore the spiritual awareness that was already there and carry out the mandate. In other verses we can find the nature of life as a test. His truth is essentially only God's and He shows who he wants and misleads who is in his will. Educational activities and activities are an important part of all creation tasks mandated by God to people. With human education formed to become caliph, to prosper the earth and become a true servant of God. For the servant of God, his life is a manifestation of the servitude of worship for the blessings of God. Scientifically the study of modern psychology has experienced significant progress, especially regarding the disclosure of the dimensions of human spirituality. Emptiness of the meaning of life will cause people to not have a strong self-esteem and make him unable to stand the suffering, lack of property, and suffering because of life experiences that are not in line with expectations. The emptiness of the human soul caused by the excitement of the treasure is a feeling of despair, a feeling of fear that is gripping so that the soul is easily disturbed and it is difficult to decide on his way of life. ${ }^{22}$

This is where the role of the priest is accompanied by thinking in an effort to discover the nature of a whole truth that when we look at the Qur'an's cues about God's command to think which basically aims to make it easier for us to believe and submit to him. That the concept of spiritual education of the Qur'an and the traditions of the Prophet Muhammad is the source of his normative footing and spiritual intuition and empirical rationality are his instruments.

The scope of spiritual education includes harmony, harmony, and balance between human relations with Allah SWT, human relations with fellow human beings and human relations with himself, and human relationships with other creatures and the environment. The scope of spiritual education is also identical with aspects of Islamic religious education because what is in it is a complementary blend of one another. The general scope of spiritual education is:

21 Haidar Putra Daulay, Pendidikan Islam, (Jakarta: Kencana, 2004), 172

22 Ibid.

Teosofia: Indonesian Journal of Islamic Mysticism, Vol. 7, No. 2, 2018 
a. Teaching of Faith Teaching of faith means the process of learning about aspects of belief, in this case, of course, beliefs according to Islamic teachings, the essence of this faith explains about religion.

b. Moral Teaching Moral teaching is a form of teaching that teaches the formation of the soul, how to behave individually in his life, this teaching means the process of teaching and learning in achieving goals so that what is taught has good character.

c. Worship Teaching Worship teachers are teaching about all forms of worship and the procedures for their implementation, which aim to be able to carry out worship properly and correctly. Understand the meaning and purpose of worship.

d. Teaching Fiqh Teaching fiqh is teaching which contains material about all forms of Islamic law that originate from the Qur'an, the Sunnah, and other shari'ah propositions. The purpose of this teaching is to find out and understand about Islamic laws and implement them daily.

e. Teaching the Qur'an Teaching the Qur'an is teaching that aims to be able to read the Qur'an and understand the meaning of the content contained in each verse of the Qur'an. ${ }^{23}$

\section{Development of the Pesantren Education System}

Since the mid-20th century, in Indonesia there have been 2 (two) types of educational system trends, namely the colonial education system (also called the modern-secular education system) and the indigenous education system which is based on the pesantren (traditional) model of education.

The colonial education system was more inclined towards aspects of general science and pragmatic skills that were intellectualistic, individualistic, and tended to westernization and Christianization. ${ }^{24}$

The colonial education system was later known as the school education model. At that time, very few native citizens had the opportunity to benefit from colonial educational institutions, because the educational institutions organized by the colonials were only for certain groups of indigenous descendants, such as aristocrats, government officials, and the like. Strictly speaking, the colonial education system was severely restricted to native Indonesians, and was actually very open to citizens of foreign descent such as China and Arabia. Apart from that, some of the indigenous people, who were predominantly adhering to the teachings of Islam at the time, considered that following the education of the colonials was something that was "forbidden", based on the secular nature and spirit of westernization and the mission of Christianization contained therein.

\footnotetext{
23 Ibid.

24 Karel A. Steenbrink, Pesantren, Madrasah, Sekolah, 24
} 
As the oldest educational institution in Indonesia, the pesantren existed long before the arrival of the colonials in the country. Basically, the pesantren education system is organized in order to educate the public (santri) to have noble personality and morality as well as deep religious understanding and practice.

The pesantren at that time already had many different types and scientific specialties. The Termas Pesantren in Pacitan, East Java, for example, is known as a pesantren specializing in "tools (structure and grammar as well as Arabic literature, and logic). While Jampes Islamic Boarding School in Kediri, is widely known as Sufism Islamic Boarding School. ${ }^{25}$ In addition, the popularity of pesantren in general is very dependent on the reputation and depth of religious knowledge possessed by caregivers (kyai).

In the colonial period, the existence of pesantren was always confronted dichotomically with the colonial education system in two opposing poles: traditional education (pesantren; native) on the one hand, and modern-secular education (schools; government) on the other. In fact, the pesantren were often regarded as a threat and resistance. Because pesantren, aside from being an educational institution, is also an "agent of social change". Take, for example, what Hasyim Asy'ari did with the pesantren which he founded in Tebuireng in 1899.

For Hasyim Asy'ari, pesantren not only function as educational institutions or religious moral institutions, but more than that, pesantren are an important means of making fundamental changes in society at large. He also believes that the pesantren tradition is a reflection of Islamic culture with its continuity and change originating from the intellectual and cultural heritage of early Javanese Muslims, especially Walisongo. This Walisongo model has been believed by all Javanese santri circles, because Walisongo is a good model for them.

Until the beginning of the decade of the 20th century, there were symptoms of development and new directions in the world of pesantren which was driven by the Pesantren Tebuireng. This is as stated by M. Yunus, historian who had visited various pesantren in the 1950s, that the birth of the Pesantren Tebuireng marked a new era of development of pesantren in Indonesia. ${ }^{26}$

Master plan of The Tebuireng Islamic boarding school designed by Hasyim Asy'ari was not in vain. He created a tradition of pesantren in himself as a diligent santri, as well as a strict but kind kiai in his family and pesantren. This last statement can be explained by observing the latest growth and development of the institution.

25 Nahrawi Djunaedi, “Kiai Haji Muhammad Hasyim Asy’ari”, Thesis, IAIN Jakarta, 1983, 20.

26 Muhammad Yunus, Sejarah Pendidikan Islam Indonesia, (Jakarta: 1983), 228-229.

Teosofia: Indonesian Journal of Islamic Mysticism, Vol. 7, No. 2, 2018 
From its inception until 1916, the Pesantren Tebuireng used the sorogan and bandongan teaching system. The form of teaching at that time was not distinguished in the classroom level. The increase in class is realized by the replacement of the book that has finished reading (khatam). The material also only revolves around Islamic Knowledge and Arabic Language. The language of instruction is Javanese with pegon letters (Arabic writing in Javanese).

Over time, the system and teaching methods in pesantren were added, including by adding "deliberation classes" as the highest class level. The number of santri entering the deliberation class is very small, because the selection is very strict. In 1916, Kyai Ma'sum Ali, the first son-in-law of Hasyim Asy'ari from his daughter named Khairiyah, introduced the classical teaching system (madrasa). This classical system (madrasa) is a teaching system adopted from Mecca.

In that year Madrasah Tebuireng also opened 7 (seven) grade levels which were divided into 2 (two) levels. The first and second years are called initial sifir and sifir tsani, which is the preparation period for students to be able to enter the madrasa in the next 5 (five) years. Early sifir and tsani sifir participants were specifically educated to understand Arabic as an important foundation for 5-year madrasa education. Starting in 1919, the Madrasah Tebuireng was officially named the Salafiyah Syafi'iyah Madrasah. The curriculum is added with Indonesian (Malay), Mathematics, and Geography material. Then after the arrival of Kyai Ilyas in 1926, lessons were added to Dutch and History lessons. In 1928, the position of Kyai Ma'sum as Head of Madrasa was replaced by Kyai Ilyas, while Kyai Ma'sum himself was appointed by Hasyim Asy'ari to establish the Seblak Islamic Boarding School (about 200 meters west of Tebuireng). ${ }^{27}$

Such is the portrait of the development of the pesantren world in the country. As an educational institution, pesantren has experienced various changes and modifications, both in terms of management and the education and teaching system. This is inseparable from the pesantren's efforts in responding to the progress and development of the times, as well as the increasingly complex demands and needs of society. This also proves that the pesantren institution since its inception has never been separated from its efforts to respond to problems that occur and are needed by the community, of course, by remaining based on traditions and noble values that exist in the midst of society.

However at this time the pesantren, as quoted by A. Saerozi, can be broadly grouped into 3 (three) types of types as follows:

a. Type A pesantren, namely pesantren where students learn and reside together with kyai in one complex, the learning curriculum is up to the kyai, with individual

27 “Sejarah Pesantren Tebuireng”, it can be accessed from http:// www.tebuireng.net/index.php. 
learning methods (sorogan) and does not organize madrasas for learning.

b. Type B pesantren, namely pesantren where students live in boarding (boarding), lessons are given by the kyai through the general stadium system (bandongan) with the material / book and the specified time, in addition students get teaching in madrasas and public schools that in the pesantren complex. In this type of pesantren, the most basic teaching lies within the madrasa

c. Type $\mathrm{C}$ boarding schools, which are boarding schools where students live in boarding (boarding), take lessons in madrassas and public schools in the pesantren complex. In this type of pesantren, the kyai only acts as supervisors and mentors of the spiritual and spiritual students. ${ }^{28}$

\section{Pesantren as the Center of Islamic Civilization in the Archipelago}

The existence and future of pesantren in the future is not without challenges. This is in line with the swift dynamics and changing times and the current of globalization which is increasingly unstoppable. All of that inevitably demands pesantren institutions to always make efforts for modification and adjustment, besides of course by continuing to endeavor to preserve the unique traditions of his pesantren as an important asset and a nation's priceless culture throughout the history of Islamic civilization in Indonesia.

Therefore, the idea of making Islamic boarding schools as the center of Islamic civilization in Indonesia is something that is very reasonable. And to realize this idea, at least in outline, efforts are needed such as: the reconstruction of pesantren education, reforming the pesantren system and management, strengthening pesantren culture, and Government policy support.

\section{Reconstruction of the Pesantren Education System}

In order to prepare pesantren institutions to face increasingly complex dynamics and contemporary world developments, the pesantren education system needs to undergo various changes and adjustments, in the sense of the need for reconstruction and reorientation so that the pesantren education system continues to exist in the future. As a traditional Islamic educational institution, pesantren education contains contents which can be broadly divided into 2 (two) categories.

The first category is the basic teaching which is a reference for the foundation of life and its solution in overcoming all life problems in the midst of socio-cultural dynamics, which have an absolute truth value and do not collapse in all the changing times. This basic teaching has a charge of universal values, which has the power of

28 Saerozi, dkk., Pendidikan Aswaja dan Ke-NU-an 3, (Surabaya: PW LP Ma'arif NU Jawa Timur, 2002), 33

Teosofia: Indonesian Journal of Islamic Mysticism, Vol. 7, No. 2, 2018 
relevance in all levels of space and time. In fact, this teaching has sacred legality and has been completely codified by the Salafus Salih scholars, namely in the form of the Qur'an and the Sunnah of the Prophet.

The second category is the teachings which are the result of interpretation and derivation of the basic teachings above. This teaching elaborates the content of basic teaching with a tendency to practical-applicative aspects. In pesantren education, generally the material that is given in an intense and simultaneous manner is more on teaching that is elaborative. Even more specifically, it can be said that a highly developed discourse and considered important in the world of pesantren is only in the field of jurisprudence.

Meanwhile, the study of basic teachings needed in an effort to understand the teachings of Islam as a whole did not receive serious attention. This can be seen from the discourse circulating in pesantren which is represented by the Yellow Book tradition. Fiqh discourse feels very dominant compared to other discourse. If such conditions are allowed to continue and escape from academic control, it is feared that the discourse of the Qur'an and the Hadith of the Prophet which in fact is a basic teaching will be increasingly forgotten altogether from pesantren education. In other words, the Qur'an and the Hadith of the Prophet will only be "lipsticks" simply because their contents are never understood directly.

In fact, the discourse of jurisprudence should not shift the position of the Qur'an or the Hadith of the Prophet. Because, fiqh is not an absolute source of guidance in all practices of life. The above concerns actually can be overcome or at least minimized, one way is to change or modify the educational methods that have been developed in the pesantren world. The educational methods applied in pesantren so far tend to be inductive. Islamic boarding schools generally develop particular studies in advance such as fiqh and various other traditions which are considered as ilm al-hâl. After mastering the particular study is considered adequate, then it will spread to other areas of study which become a tool in understanding basic teachings.

The results of pesantren education will certainly be different if the inductive method that has been going on is reversed by using the deduction method, which is to develop studies that are tools to understand basic teachings first, then then implement them in particular studies such as fiqh and other studies surrounding the development of modern dynamics. This method seems to be more able to develop the process of reasoning, creativity, and dynamics in understanding Islam more contextually than just the first method (induction) which emphasizes doctrinal understanding. Another aspect that needs to be seen in building a pesantren education system in the future is the curriculum problem.

The pesantren curriculum, represented by the Yellow Book, only emphasizes the areas of jurisprudence, theology, Sufism, and language. Such a state of pesantren 
education curriculum has a consequence on pesantren exclusivism from other discourses and thoughts, except for thoughts developed by Syafi'i, Ash'ari, and AlGhazali schools. In fact, almost all Islamic teachings are only understood as far as the teachings concerning fiqh, theology, and Sufism developed by the three figures. The implication is the loss of critical, analytical and reflective culture in the pesantren education tradition. Academic freedom is hardly recognized anymore and the munazharah system is also missing from the pesantren tradition.

In this context, the effort that needs to be done in pesantren education is to build "truths" that have taken root in the pesantren world to become more open for new ijtihad efforts in the face of contemporary world developments. That way the pesantren curriculum must be more open to the development of contemporary science that continues to develop.

\section{Revamping the Pesantren Education System and Management}

The next effort that needs to be done in order to make pesantren as the center of Islamic civilization in Indonesia is to reform the pesantren system and management. This is important to remember the success of the pesantren education system is very much influenced by its managerial arrangement.

So far, pesantren management patterns generally tend to be done incidentally and do not pay attention to the goals that are systematized first. The pesantren education system is usually done naturally with a constant managerial pattern every year. Fundamental changes in the management of pesantren are apparently not yet seen. The problem of accepting new students, for example, is still done openly for all individuals who clearly have diverse backgrounds and abilities without first conducting a pre-test effort. In other words, the qualitative categorization and classification of santri has never been undertaken.

Therefore, pesantren management must be pursued more openly. Therefore, developments that occur outside must be known and anticipated, especially the possibilities for collision. This necessity necessitates the need for a pattern of symbiotic-mutualistic cooperation between pesantren and other institutions that are considered capable of contributing and creating transformational nuances. This pattern of cooperation can also be carried out in efforts to develop pesantren resources in order to empower itself in facing increasingly complex contemporary challenges. This pattern of collaboration will automatically minimize the negative assumptions that have been embedded in pesantren institutions, such as isolated, alienated, exclusive, conservative, and the tendency to maintain the status quo.

If so, then the direction of the development of the pesantren world in the fut ure can be expected to take various forms. There are pesantren whose form remains the same as before, namely as a non-formal educational institution that specializes in

Teosofia: Indonesian Journal of Islamic Mysticism, Vol. 7, No. 2, 2018 
studying the religious sciences, which emphasizes the importance of religious practice in daily life, where the teachings are sourced from the results of ijtihad of jurisprudents and Sufists with books classic book. There are also pesantrens which are non-formal in the religious field. Yet, they equipped students with various types of skills. The field of religious studies continues to be developed in accordance with the development of thought in Islam, so it is not only limited to the sources of old teachings that are fiqhsufistic, but also equipped with the teaching of philosophy and new thoughts in Islam in accordance with the development era.

Among the most important things for the pesantren system in the future is the provision of formal education, both madrassas and public schools to universities that live in a pesantren environment. This form will certainly make boarding schools survive in the future, because they will complement each other as boarding schools as non-formal education working on the tafaqquh fiddin values and religious practice, with formal education working on other sciences.

In addition, renewal of the concept of boarding in the future is also needed so that pesantren are able to declare their presence as a stable national education subsystem in the future. Pesantrens in the future should not only be places to live together for 24 hours from year to year as the condition of the pesantren today, but also as hostels that function as a joint study forum that can creatively and innovatively develop science, technology, and religion, in accordance with the challenges of his day and develop the potential of the individuality or identity of each of its members in balance with the development of the collective personality.

Through these efforts, in turn the face of pesantren education will no longer be considered static or stagnant. The dynamics of the pesantren education life must continue, because indeed the pesantren has been proven by its active involvement and participation in providing services to the community in many aspects of life that always accompany it. Because boarding schools are educational institutions that have strong cultural roots in the community. ${ }^{29}$

\section{Strengthening Pesantren Culture}

Although on the one hand pesantren are required to be more open in adopting and adapting themselves to the development of the contemporary world, pesantren must also maintain and strengthen the cultures that have become their trademarks. The principle of independence that has existed in pesantren, for example, is an educational pattern that needs to be continually developed in shaping the personality of an independent national generation. Because, since the beginning the students in the pesantren have been trained independently. He regulates and is responsible for his own

29 Sa'id Aqiel Siraj, Pesantren Masa Depan, (Bandung: Pustaka Hidayah, 1999), 181 
needs, such as arranging spending money, cooking, washing clothes, planning studies, and so on. Such a principle is certainly a distinct advantage possessed by pesantren in shaping the personality of students, and is not possessed by formal schools in general.

In addition, attitudes such as tawazun, tasamuh, tawassuth, which have become the characteristics of pesantren, are cultures that also need to be strengthened. For this reason, it also includes efforts that need to be made to make boarding schools as the center of Islamic civilization in Indonesia is to make the principles of education and culture in boarding schools as principles that also apply in other educational institutions. That is, the principles and culture of pesantren education need to be used as an alternative that can be adopted by the school education system or other formal education institutions.

\section{Government Policy Support}

To make pesantren as the center of Islamic civilization in Indonesia, the existence of Islamic boarding schools in the national education system is not enough to be seen merely as a sub-system, but must be seen as a "partner" in efforts to educate the nation's life. The position of pesantren which integrates in the national education system has so far been reflected in various aspects. First, national education makes religious education one of the mandatory contents in all lines and levels of education. Second, in the national education system the pesantren is positioned parallel with formal education, so that the position becomes the same, there is no sub-ordination of pesantren education. ${ }^{30}$

Benchmarks that must be held in the implementation and implementation of national education include: (a) national education adheres to the principle of lifelong education; (b) national education is a shared responsibility between family, community and government; and (c) national education is directed to shape Indonesian people as a whole.

In this framework, the existence of pesantren becomes important in the scheme of achieving national education goals. Because, the final estuary of the goal of national education is to form a dignified human being. This is in line with the function of national education as stipulated in UUSPN Number 20 of 2003, that national education functions to develop capabilities and shape the dignified character and civilization of the nation in the context of educating the life of the nation, and aims at developing the potential of students to become human beings who believe and be devoted to God Almighty, noble, healthy, knowledgeable, capable, creative, independent and become a democratic and responsible citizen.

30 Mukhtar Maksum, Madrasah, Sejarah dan Perkembangannya, (Jakarta: Logos Wacana Ilmu, 1999), 159

Teosofia: Indonesian Journal of Islamic Mysticism, Vol. 7, No. 2, 2018 
From the formulated function of national education above, it is clear that a nation with dignity is a nation that has the following characteristics: (1) having faith; (2) be cautious; (3) noble character; (4) physically and mentally healthy; (5) knowledge; (6) capable and creative; (7) independent; (8) democratic; and (9) take responsibility. The achievement of a dignified nation as the ultimate goal of the implementation of national education with the characteristics as mentioned above, actually has been built by pesantren education since its inception until now. ${ }^{31}$

Therefore, this is where the importance of placing pesantren is seen not as part (sub-system) of national education, but rather as a "partner". Therefore, the achievement of national education goals has actually been run by pesantren as is known from the basic principles of pesantren education as said by Mastuhu, ${ }^{32}$ namely: (1) theocentric; (2) voluntary and dedicated; (3) wisdom; (4) simplicity; (5)collectivity; (6) arranging joint activities; (7) guided freedom; (8) independent; (9) a place to seek knowledge and serve; (10) practice religious teachings; (11) without a diploma; and (12) blessing of the clerics.

Pesantren education can clearly shape the dignity of believing and pious nations, because pesantren education adheres to theocentric principle, which is the view that all events originate, proceed, and return to God's truth. All educational activities in pesantren are seen as worship to God. All educational activities are an integral part of the totality of life, so learning in pesantren is not seen as a "tool" but is seen as a "goal". Therefore, teaching and learning activities in the pesantren do not take into account the matter of time, so that life in its daily life is always based on worship only to Allah, and the orientation of his life is clear that his worship and life and death are solely due to God.

The principle of pesantren education of course would be easier to shape the dignity of students / students into people of faith and pious, especially at the same time also directly practiced in everyday life. This is of course different from the education carried out in schools in general. Therefore, it is appropriate if the formation of people of faith and piety as the goal of national education, can actually be done by an education system that adheres to the principles of education that prioritizes theocentric philosophy as in pesantren. Such a principle will in turn shape the noble character or noble character of the nation.

\section{Closing}

From the descriptions above, several conclusions can be drawn as follows. First, pesantren is the oldest Islamic educational institution in the archipelago. Its action in

31 See acts number. 20 2003, (Jakarta: Citra Umbara, 2008), 7
32 Mastuhu, Dinamika Sistem Pendidikan Pesantren, (Jakarta: INIS, 1994), 62-66. 
advancing the nation cannot be underestimated. Education in pesantren itself is known to be holistic and comprehensive, by placing aspects of morality, divinity, and human dignity as a whole that is substantial, as well as the nature and core purpose of education. Islamic boarding schools have at least a tradition including the tradition of reading the yellow book and others. With this tradition, pesantren is not only able to carry out its main mission of giving birth to scholars, promoting Islamic teachings, and planting Islamic traditions, it also causes pesantren to continue to exist and survive to the present.

Second, the idea of the idea of making Islamic boarding schools as the center of Islamic civilization in Indonesia is something that is very reasonable. That reason can at least be explained from the perspective of the pesantren's historical review. Historically, the pesantren is the oldest Islamic education institution in Indonesia with many unique and diverse potentials which necessitates that the institution be the center of Islamic civilization in Indonesia.

Third, the efforts that need to be made in order to make pesantren as the center of Islamic civilization in Indonesia must at least work on 4 (four) key elements, namely: reconstruction of pesantren education, reforming pesantren system and management, strengthening pesantren culture, and Government policy support. 


\section{Bibliography}

Abdul Fatah, Rohadi, dkk., Rekonstruksi Pesantren Masa Depan, Jakarta: PT. Listafariska Putra, 2005.

Djunaedi, Nahrawi, Kiai Haji Muhammad Hasyim Asy'ari, tesis di IAIN Jakarta, 1983.

Haedari, Amini, dkk., Masa Depan Pesantren dalam Tantangan Modernitas dan Tantangan Kompleksitas Global, Jakarta: IRD Press, 2004.

http:// www.tebuireng.net/index.php.

M. Echol, Jhon dan Hasan Shadily, Kamus Inggris Indonesia, Jakarta: Gramedia, 1980

M. Zamzami, dkk., Islam Ahlussunnah Waljama'ah di Indonesia: Sejarah, Pemikiran, dan Dinamika Nahdlatul Ulama, Jakarta: Pustaka Ma'arif NU, 2007.

Maksum, Mukhtar, Madrasah, Sejarah dan Perkembangannya, Jakarta: Logos Wacana Ilmu, 1999.

Mastuhu, Dinamika Sistem Pendidikan Pesantren, Jakarta: INIS, 1994.

Mastuki, HS, dan M. Ishom El-Saha (eds.), Intelektualisme Pesantren: Potret Tokoh dan Cakrawala Pemikiran di Era Pertumbuhan Pesantren, Jakarta: Diva Pustaka, 2003.

Nata, Abudin, Pendidikan Islam dengan Pendekatan Multidisipliner, Jakarta: PT RajaGrafindo Persada, 2010.

Saerozi, dkk., Pendidikan Aswaja dan Ke-NU-an 3, Surabaya: PW LP Ma'arif NU Jawa Timur, 2002

Siraj, Sa’id Aqiel, Pesantren Masa Depan, Bandung: Pustaka Hidayah, 1999.

Steenbrink, Karel A, Pesantren, Madrasah, Sekolah, Jakarta: LP3ES, 1974. UndangUndang No. 20 Tahun 2003, Jakarta: Citra Umbara, 2008.

Van Brunessen, Martin, Kitab Kuning: Pesantren dan Tarekat, Bandung: Mizan, 1999.

Yunus, Muhammad, Sejarah Pendidikan Islam Indonesia, Jakarta: 1983.

Zamakhsyari Dhofier, Tradisi Pesantren, Jakarta: LP3ES, 2002. 